\title{
Modernization in the Christian Worship of Surabaya City in the Pandemic
}

\author{
Jessica Kristinova ${ }^{1, *}$ Agus Machfud Fauzi ${ }^{2}$
}

\author{
${ }^{1}$ Universitas Negeri Surabaya \\ ${ }^{2}$ Universitas Negeri Surabaya \\ *Corresponding Author. Email: jessicaclaudia.20005@mhs.unesa.ac.id
}

\begin{abstract}
Currently, modern technology is a necessity for people to carry out activities. In the current pandemic era, people depend on technology to communicate. In addition to communicating, technology also helps people to carry out worship according to their respective beliefs. One of them is for Christians. Worship that is usually done in the church must be done online during the pandemic. However, it turns out that modernization in Christian worship has both negative and positive impacts. The purpose of this study was to determine the online worship liturgy according to Christians, to find out the opinions of Christians about modernization in worship, to analyze the impact of modernization, and to find out the efforts made so that modernization can be carried out optimally. This research uses descriptive quantitative method. Data was collected through questionnaires filled out by Christians in Surabaya from several streams, literature studies and observations. This study uses Max Weber's theory of value rationality. The result of this study is that modernization has a positive effect on the worship of Christians in the city of Surabaya, because it can make it easier when going to worship and can be an alternative for worship in the midst of a pandemic.
\end{abstract}

Keywords: Modernization, Worship, Pandemic

\section{INTRODUCTION}

The pandemic in Indonesia has been going on for almost two years. Many things have changed as a result of this pandemic. Starting from the habit of wearing masks, maintaining distance, limiting community activities, and other new habits. One of the habits that have changed is the habit of religion. The term religion in general comes from the word "a" which means not, and "gama" which means chaotic. So religion means not messed up. This is because religion is one way to regulate human behavior and actions so that the social system in society does not become chaotic. Some opinions from experts about religion are much debated. According to Turner (2012) religion can be interpreted differently by each person or is subjective. Another definition of religion is belief in spiritual matters (Tylor, 1832-1917). Sociologists such as Durkheim also shared his opinion about religion, namely that religion is one of the interdependent parts consisting of aqidah and worships, all of which are connected with sacred things. Indonesia has six official religions that are recognized by the state. Changes in the way of worship occur in all religions. One of them is Christianity. Christianity is a religion taught by Jesus Christ or generally known as Isa
Almasih. Christianity was born in the city of Jerusalem and then developed and spread in several areas. Its spread was brought by colonizers from the Spanish, Portuguese, and Dutch. The entry of Christianity in Indonesia occurred in the 7th century through the Eastern Assyrian church in Sumatra. Then during the Dutch colonial era, The spread of Christianity in Indonesia is getting wider. Based on data from the 2010 population census, Christians in Indonesia are as follows in Table 1.

The Table 2 shows that there are 539,847 followers of Protestant Christianity in Surabaya. This makes Surabaya the area that has the most adherents in East Java. The current pandemic has resulted in changes in the worship of Christians. The change is in the form of the inclusion of modernization in the existing church and spiritual fellowship. Although modernization has long entered the church, however, during the current pandemic, worship depends on the use of modernization. Modernization is one part of directed social change (Soekanto, 2015). Modernization in the view of JW Schoorl (1990) is a change in production techniques from traditional methods to the industrial revolution. In general, modernization is a change in 
society from traditional to modern society. Modernization is closely related to technology, globalization, and westernization. Technology in the current pandemic era plays an important role in supporting individual communication and interaction processes. Technology also helps in the way Christians worship. The use of internet media and advanced technology is currently needed by the church so that worship can still be carried out.

Table 1 Data on Religious Adherents in Indonesia 2010

\begin{tabular}{lll}
\hline Religion & $\begin{array}{l}\text { Number of } \\
\text { Followers }\end{array}$ & Percentage \\
\hline Islam & 207.176 .162 & 87.18 \\
\hline Christian & $16,528,513$ & 6.96 \\
\hline Catholic & $6,907,873$ & 2.91 \\
\hline Hindu & $4,012.116$ & 1.69 \\
\hline Buddha & $1,703,254$ & 0.72 \\
\hline KhongHu Cu & 117,091 & 0.05 \\
\hline Other & 299,617 & 0.13 \\
\hline $\begin{array}{c}\text { Not } \\
\text { answered }\end{array}$ & 139,582 & 0.06 \\
\hline Not Asked & 757,118 & 0.32 \\
\hline Amount & $237,641,326$ & 100 \\
\hline
\end{tabular}

Based on the table, it can be seen that the population who adheres to Christianity is $6.96 \%$ of the total population of Indonesia

Table 2 Data on Religious Adherents in East Java Province 2016

\begin{tabular}{|c|c|c|c|c|c|c|}
\hline \multirow{2}{*}{$\begin{array}{c}\text { Coun } \\
\text { ty/Cit } \\
y\end{array}$} & \multicolumn{6}{|c|}{$\begin{array}{l}\text { NUMBER OF RELIGION IN EAST JAVA } \\
\text { IN } 2016\end{array}$} \\
\hline & Islam & $\begin{array}{c}\text { Prote } \\
\text { stant }\end{array}$ & $\begin{array}{l}\text { Cath } \\
\text { olic }\end{array}$ & $\begin{array}{c}\mathrm{Hin} \\
\mathrm{du}\end{array}$ & $\begin{array}{l}\text { Bud } \\
\text { dha }\end{array}$ & $\begin{array}{l}\text { Ot } \\
\text { her }\end{array}$ \\
\hline Poor & $\begin{array}{c}1,754,0 \\
09\end{array}$ & $\begin{array}{c}51,76 \\
5\end{array}$ & $\begin{array}{c}43,4 \\
24 \\
\end{array}$ & $\begin{array}{l}56, \\
426 \\
\end{array}$ & $\begin{array}{c}9,62 \\
1 \\
\end{array}$ & $\begin{array}{c}28 \\
7 \\
\end{array}$ \\
\hline $\begin{array}{l}\text { Probo } \\
\text { lingg } \\
\mathrm{o} \\
\end{array}$ & $\begin{array}{c}215,61 \\
1\end{array}$ & 3.072 & $\begin{array}{c}7,93 \\
5\end{array}$ & $\begin{array}{l}7,4 \\
93\end{array}$ & $\begin{array}{c}1,90 \\
8\end{array}$ & 63 \\
\hline $\begin{array}{l}\text { Pasur } \\
\text { uan }\end{array}$ & $\begin{array}{c}167,49 \\
7\end{array}$ & 5780 & $\begin{array}{c}5.53 \\
2\end{array}$ & $\begin{array}{l}31 \\
827\end{array}$ & $\begin{array}{c}1,84 \\
3\end{array}$ & 83 \\
\hline $\begin{array}{l}\text { Mojo } \\
\text { kerto }\end{array}$ & $\begin{array}{c}125,88 \\
3\end{array}$ & $\begin{array}{c}13,50 \\
3\end{array}$ & $\begin{array}{c}5.55 \\
6\end{array}$ & $\begin{array}{l}1,4 \\
59\end{array}$ & $\begin{array}{c}4.25 \\
0\end{array}$ & 97 \\
\hline $\begin{array}{l}\text { Madi } \\
\text { son }\end{array}$ & $\begin{array}{c}180,81 \\
1\end{array}$ & $\begin{array}{c}539,8 \\
47\end{array}$ & $\begin{array}{l}145, \\
300\end{array}$ & $\begin{array}{l}23 \\
372\end{array}$ & $\begin{array}{c}40,0 \\
24\end{array}$ & $\begin{array}{r}2,7 \\
58\end{array}$ \\
\hline $\begin{array}{l}\text { Surab } \\
\text { aya }\end{array}$ & $\begin{array}{l}2,499,1 \\
16\end{array}$ & $\begin{array}{c}539,8 \\
47\end{array}$ & $\begin{array}{l}145 \\
300\end{array}$ & $\begin{array}{l}23 \\
372\end{array}$ & $\begin{array}{c}40,0 \\
24\end{array}$ & $\begin{array}{c}2,7 \\
58\end{array}$ \\
\hline
\end{tabular}

Previous research conducted by Santi Mongan with the title "The Influence of Online Worship on Spiritual and Social Transformation in the GKII Jamaat's People" explained that online worship carried out using digital equipment is not something that eliminates the essence of worship. Because the researcher argues that the church is a fellowship built on faith. This study focuses on the Christian faith and the true meaning of worship. However, the researcher did not provide data analysis that could support his research and did not analyze the right solution so that online worship can run well during the pandemic.

Another study entitled "The Dynamics and Challenges of Islamic Society in the Era of Modernization (Thoughts and Contributions Towards Civil Society)" analyzes the inclusion of modernization in Muslim worship. According to the researcher, there are four orientations in thinking about modernization. There are also various groups that have responded differently to modernization. This research is supported by the existence of verses in the Qur'an related to modernization. However, this study does not explain in detail about the impact that occurs from the inclusion of modernization in Muslim worship. Researchers are also lacking in data supporting responses from the community who are the object of research.

According to Langfan in his research entitled "Online Worship in the Time of the Covid-19 Pandemic: Implementation of Hebrews 12:28", online worship during the Covid-19 pandemic is very much needed by the congregation. The results of his research, namely that online worship that is carried out does not run optimally, the congregation tends to not respect God when worshiping online at home. This is one of the negative impacts of online worship. This research was conducted using the perspective of religious theory. The researcher also explains the definitions of worship in Christianity. However, this research focuses too much on the Christian religious perspective and is not studied using social science or science in general. So, the general public can consume this research.

\section{METHODS}

This study uses a descriptive quantitative approach. This research was conducted using descriptive analysis quantitative research methods. According to (Sugiyono: 2011), quantitative methods are research methods based on the philosophy of positivism, used to examine certain populations or samples. Quantitative methods are referred to as traditional methods, because they have long been used and have become a tradition for research. Descriptive method according to Sugiyono is a method used to describe or analyze a research result but is not used to make broader conclusions. According to M. Nazir (2013), that is a method in researching a group of people with a system of thought or a class of events in the present to make a descriptive or systematic picture. From the two definitions, it can be concluded that the descriptive method is a method that provides a 
systematic description of the data that has been obtained. This approach is used so that researchers can find out the causal relationship of the problems discussed. The theory used in this research is Max Weber's theory of value rationality. According to Weber (Johnson, 1981: 221), value rationality is used as an object of conscious consideration and calculation. Value rationality is often associated with religious activities that affect individuals. In religion, it has values that are only obtained through the presence of God. This theory is used, because in the modernization of Christians during the pandemic there are values that can still be felt by Christians. Although, worship is done online so you can't feel the presence of God directly. The main purpose of worship is value. Theory in a study is a guideline or foundation on which a research is based. Without theory, the knowledge and research carried out cannot be taken for granted and are merely facts.

Data was collected through questionnaires, literature study, and observation. Questionnaires are data collection techniques that are carried out by giving questions or written statements to respondents to be answered (Sugiyono, 2013: 142). Respondents are Christians who perform online worship during the pandemic. Respondents came from various churches and sects. Literature study is used to support data related to the topic of this research. Data was collected through reviewing books, literature, notes, and other supporting documents. Other documents can be articles, news media, and reports on previous research. The observation used by the researcher is participatory observation, that is, the researcher is involved with the activity being observed. This is because, researchers experienced online worship in the pandemic period and felt modernization in worship.

\section{RESULTS AND DISCUSSION}

\subsection{Differences in Liturgy between Online and Offline Worship}

Based on the Circular of the Minister of Religion No. SE 23 of 2021 regarding the Implementation of Worship/Religious Activities in Places of Worship during the PPKM Period, there are provisions related to the limited duration of worship. In the circular, it is stated that places of worship may only carry out worship/religious activities for a maximum of one hour. The existence of these regulations resulted in changes and differences in the worship of Christians. Therefore, the researchers grouped them in table 3 below.
Table 3 Liturgical Differences in Christian Worship during the Pandemic

\begin{tabular}{|c|c|c|}
\hline No. & Before the Pandemic & During the Pandemic \\
\hline 1. & $\begin{array}{l}\text { Worship is held for } 1 \text { - } \\
2 \text { hours }\end{array}$ & $\begin{array}{l}\text { Worship is carried } \\
\text { out for a maximum } \\
\text { of } 1 \text { hour }\end{array}$ \\
\hline 2. & $\begin{array}{l}\text { Praise and worship } \\
\text { consists of } 3-5 \text { songs }\end{array}$ & $\begin{array}{l}\text { Praise and worship } \\
\text { consists of } 3 \text { songs }\end{array}$ \\
\hline 3. & $\begin{array}{l}\text { Delivery of lectures } \\
\text { or sermons is carried } \\
\text { out for } 30-45 \text { minutes }\end{array}$ & $\begin{array}{l}\text { Delivery of lectures } \\
\text { or sermons is carried } \\
\text { out for } 30-40 \text { minutes }\end{array}$ \\
\hline 4. & $\begin{array}{l}\text { There is a collection } \\
\text { pocket for offerings }\end{array}$ & $\begin{array}{l}\text { Offerings are made } \\
\text { by online transfer via } \\
\text { the application }\end{array}$ \\
\hline 5. & $\begin{array}{l}\text { The testimony of the } \\
\text { congregation was } \\
\text { delivered after the } \\
\text { delivery of the } \\
\text { church's news }\end{array}$ & $\begin{array}{l}\text { The testimony of the } \\
\text { congregation is } \\
\text { delivered online via } \\
\text { video recording }\end{array}$ \\
\hline 6. & $\begin{array}{l}\text { The congregation } \\
\text { shakes hands and } \\
\text { greets God's servants } \\
\text { when entering the } \\
\text { worship room }\end{array}$ & $\begin{array}{l}\text { The congregation } \\
\text { only greets God's } \\
\text { servants when they } \\
\text { enter the worship } \\
\text { room }\end{array}$ \\
\hline
\end{tabular}

At the beginning of the implementation of the liturgy during the pandemic, the congregation felt strange and strange because the habits in worship were changed. However, over time the congregation began to adapt and apply the liturgy in every worship in the church. Each church with its own sect is trying to make their liturgy adaptable to the pandemic conditions.

\subsection{Modernization in Worship}

Modernization is synonymous with the use of technology. Technology is growing every day. Modernization can also be interpreted from traditional changes to changes according to the times. This happened in the worship performed by Christians during the pandemic. Worship depends on the technology used. Before the pandemic, technology was already in use. However, maximum use is only done during the pandemic. Currently there are a lot of media that can help when going to worship. Social media such as, Instagram, Facebook, Youtube, Twitter or video conferencing applications such as Zoom and Google 
Meet. To support the ongoing worship, other facilities and software are needed. Tools needed such as camera, soundcard, webcam. Required computer software such as OBS.

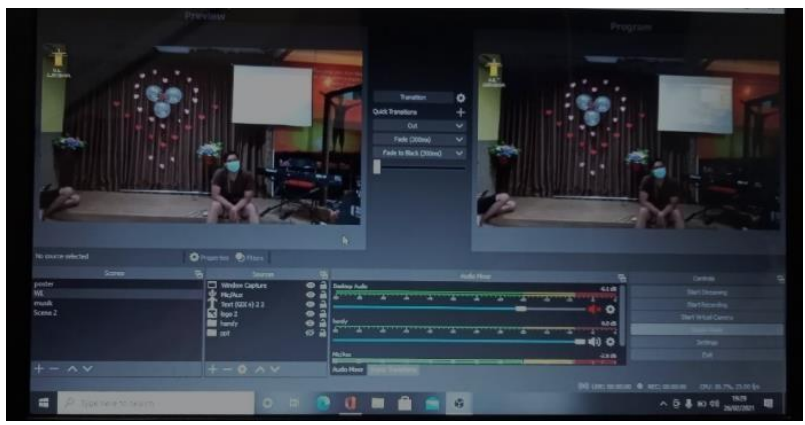

Figure 1 The examples of Modernization in Using OBS Software

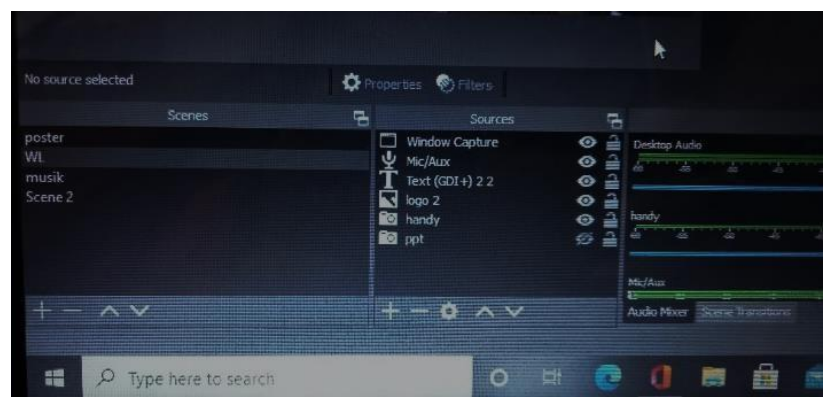

Figure 2 The examples of Modernization in Using OBS Software

In addition to the need for facilities and infrastructure, the church also needs the assistance of human resources to operate these facilities. Online worship is carried out by every church program, such as Sunday worship services, children's worship, youth worship, youth worship, meetings, and coordination. Here are examples of using Zoom and Youtube applications for worship.

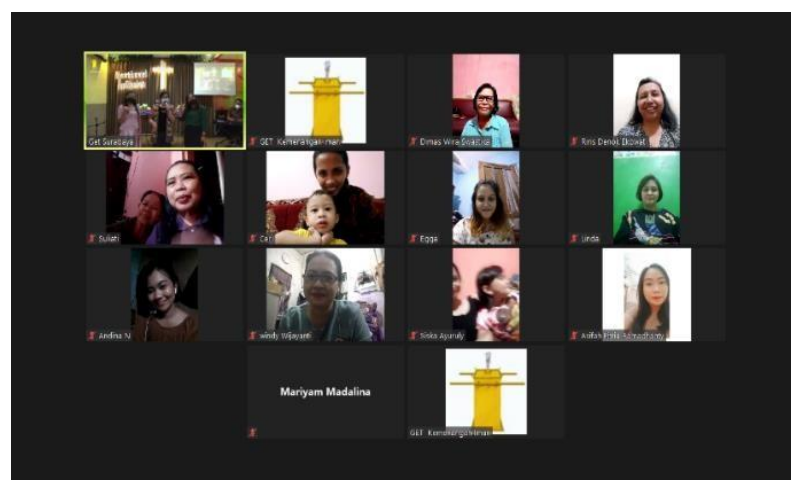

Figure 3 Using the Zoom Application at Worship

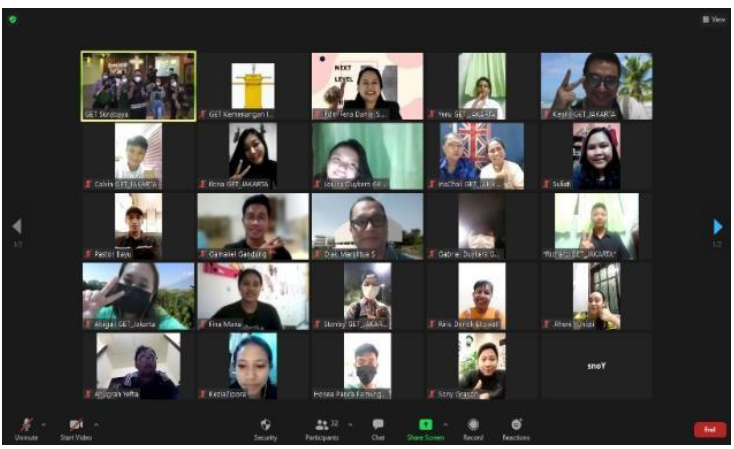

Figure 4 Using the Zoom Application in Youth Worship

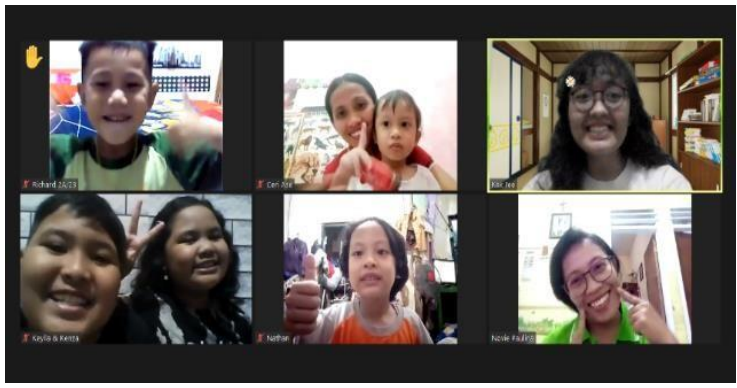

Figure 5 Using the Zoom Application in Children's Worship

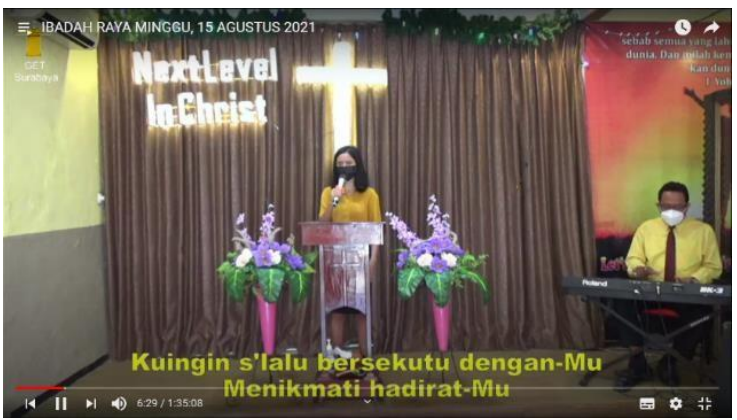

Figure 6 Using Streaming Applications

The church is trying very hard so that worship can still be carried out even though it is hindered by distance. This is so that individuals still have value rationality. With the modernization of worship can be done flexibly and efficiently. Worship can be done anywhere and anytime according to the conditions of individuals who follow the Christian religion.

\subsection{Christian Responses to Modernization in Worship}

This study uses quantitative methods to find out the opinions and responses of Christians regarding modernization in worship during the pandemic. The questionnaire was filled out by 31 respondents with various church backgrounds and sects. 


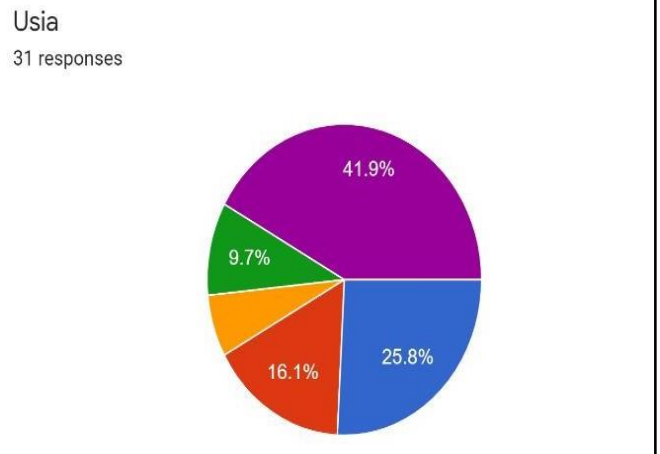

Figure 7 Respondent's Age

Most of the questionnaires were filled by respondents aged over 36 years. This age can be categorized as an adult congregation who attends religious services every week.

Table 4 Respondent's Church Origin

\begin{tabular}{cll}
\hline No. & $\begin{array}{c}\text { Number of } \\
\text { Respondents }\end{array}$ & \multicolumn{1}{c}{ Church } \\
\hline 1. & 11 & $\begin{array}{l}\text { GET Kemenangan Iman } \\
\text { Surabaya }\end{array}$ \\
\hline 2. & 5 & GBI Gibeon Surabaya \\
\hline 3. & 2 & GSKI Bethany Juanda \\
\hline 4. & 2 & GSKI Bethany Nginden \\
\hline 5. & 1 & BMC Sumur Welut \\
\hline 6. & 1 & GBI Nazareth \\
\hline 7. & 1 & GPIB Nazareth \\
\hline 8. & 1 & GPIB Genta Kasih \\
\hline 9. & 1 & GEKARI \\
\hline 10. & 1 & Gereja Pentakosta \\
\hline 11. & 1 & GKI Lebak Jaya \\
\hline 12. & 1 & GKJW Manukan \\
\hline 13. & 1 & GKJW Ngagel \\
\hline 14. & 1 & HKBP Surabaya \\
\hline 15. & 1 & Pikumene Juanda \\
\hline & & \\
\hline
\end{tabular}

Based on Table 4, there are several streams of respondents who filled out the questionnaire. GET
Church of the Victory of Faith, GBI Gibeon, GSKI Bethany, BMC Sumur Welut, GEKARI, GBI Nazareth are charismatic churches. This means that modernization is easy to implement because the church is fast in keeping up with the times. In contrast to the synod churches GPIB, GKJW, HKBP, GKI which are more strict and disciplined in the implementation of their worship. This can be proven by the different liturgy of the charismatic church. However, the current pandemic is forcing the church to adapt to modernization.

Apakah pandemi menghalangi anda untuk beribadah?

31 responses

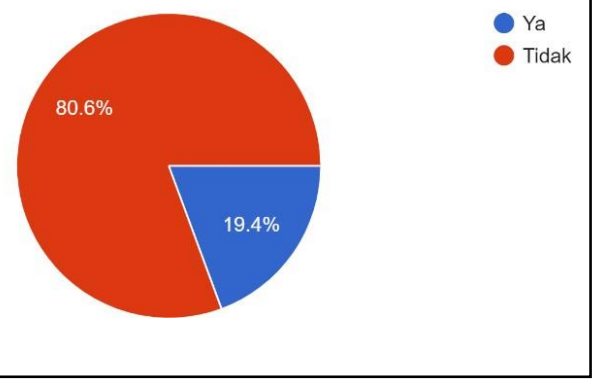

Figure 8 Worship in the Time of a Pandemic

Researchers ask questions according to the diagram. $80.6 \%$ of respondents answered that the pandemic did not prevent them from worshiping. Another $19.4 \%$ of respondents answered that the pandemic prevented them from worshiping. This difference in answers could be due to the church background of each respondent.

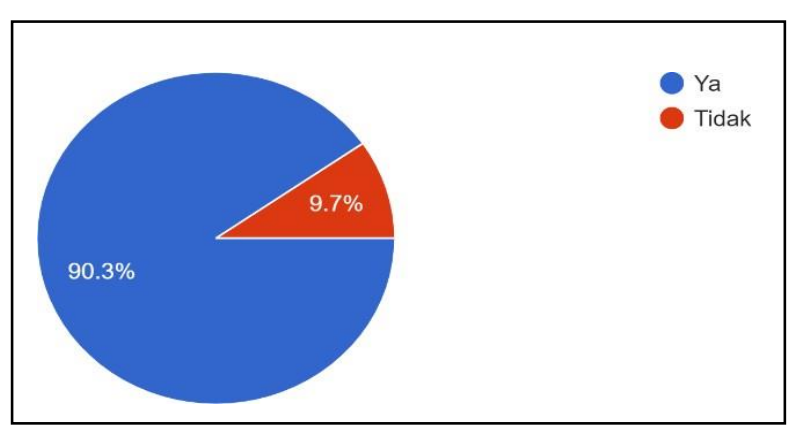

Figure 9 Churches Conducting Worship Online

Of the 31 respondents, almost all of them answered that their church conducts online worship such as streaming Youtube or Zoom Meetings. There were 9.7\%, namely 3 other respondents who answered that the church did not hold online worship services. Based on the answers to the questionnaire, it can be seen that modernization in the form of technology has been applied by every church sect and synod. 


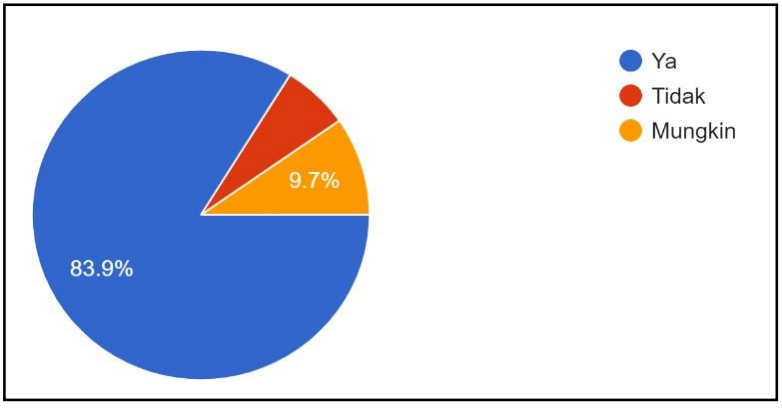

Figure 10 Respondents' Responses to the Effect of Modernization

The diagram shows that $83.9 \%$ of the answers, namely 26 respondents answered that modernization had a big impact on the worship of Christians. Respondents who answered according to the current perceived condition. As many as $9.7 \%$ of the answers, namely 3 respondents answered that modernization might have a big influence on the worship of Christians.

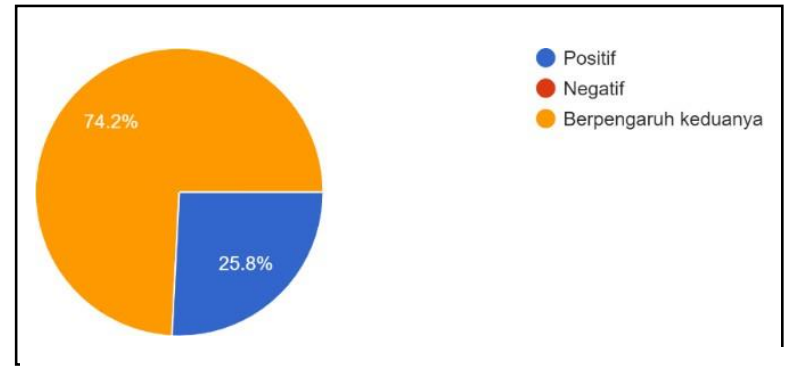

Figure 11 Respondents' Responses to the Effect of Modernization

The remaining two respondents answered that modernization had no major effect on worship. There were $74.2 \%$ of the answers, namely 23 respondents who answered that modernization had a positive and negative effect on Christian worship. However, there were also respondents who answered that modernization only had a positive effect on Christian worship. The results of the respondents' answers can be analyzed to determine the impact of the modernization of worship. The positive impacts of modernization of worship include, 1) Worship can be carried out flexibly, 2) Worship is not limited by space and time, 3) Makes it easier for individuals to invite people around them to join in worship, 4) Churches can develop easily over time, 5) Reducing people's mobility during the pandemic. As for the negative impacts of modernization in worship, among others, 1) Worship is not followed by a respectful attitude or a solemn attitude because of many disturbances, 2) Low interaction between church members, 3) Decreased spiritual value obtained from worship, 4) Additional expenses for the congregation to buy quota packages when participating in online worship, 5) Worship feels boring and boring because there is no interaction between congregations. The positive and negative impacts are adjusted to the spiritual condition of the congregation in each church. If the congregation has a mature spiritual condition, then the negative impact can be reduced or even nonexistent. It happens the other way around The positive and negative impacts are adjusted to the spiritual condition of the congregation in each church. If the congregation has a mature spiritual condition, then the negative impact can be reduced or even non-existent. It happens the other way around The positive and negative impacts are adjusted to the spiritual condition of the congregation in each church. If the congregation has a mature spiritual condition, then the negative impact can be reduced or even non-existent. It happens the other way around.

\subsection{Efforts to Face Modernization in Christian Worship}

Based on the conditions from the previous explanation, there are several efforts needed by the church in maximizing modernization during the pandemic. These efforts include the use of social media and video conferencing applications. These efforts include, 1) Participating in learning or seminars to develop potential and abilities, 2) Sharing worship links and inviting fellow Christians to worship, 3) Creative in managing content on social media so that other Christians are interested in worship. 4) The church continues to strive to develop the facilities needed so that online worship can be carried out smoothly. Such efforts require the active participation of church administrators and member congregations. Both parties must work together to face modernization wisely. If modernization is not addressed in a wise manner, It distances Christians from the rationality of values and not helps to obtain them.

\section{CONCLUSION}

Modernization is currently entering into every aspect of human life. Modernization in the form of technology helps humans in carrying out their activities. In the era of the pandemic, modernization is the main character for the survival of religious people. Not only Christianity, Islam, Catholicism, Hinduism, Buddhism, and Confucianism feel a modernization in worship. Modernization can happen well if we respond to it properly. However, nowadays there are many mistakes made by some churches. There are still churches that are closed and resist modernization. Old-fashioned thinking that harms many people should be able to be changed through socialization and guidance from nearby religious institutions. In addition, modernization prevents congregations from meeting face-to-face. However, the role of church administrators and ministers of God to interact with the congregation must be maintained. Modernization in Christian worship brings a big impact and tends to be positive. Therefore, churches and congregations are expected to adapt quickly so that the goal of rationality of values for each individual can be achieved properly. 


\section{REFERENCES}

[1] Anon. 2021. "Surat Edaran Nomor SE. 23 Tahun 2021 Tentang Pelaksanaan Kegiatan Peribadatan Selama PPKM."

[2] Adnan, Gunawan. 1967. Sosiologi Agama: Memahami Teori Dan Pendekatan.

[3] Fauzi, Agus Machfud. 2017. Sosiologi Agama. Surabaya.

[4] Fauzi. Agus Machfud, Maliha. Novie Filia, Mustofa. 2021. "Javanese-Mataraman Muslim Obedience Toward Religious and State Leaders in Performing Friday Prayers During the Covid-19 Pandemic". Jurnal Studi Keislaman.

[5] Fransiskus Irwan Widjaja, Fredik Melkias Boiliu, Didimus SB Prasetya, Haposan Simanjuntak, Vicky BGD Paat. 2021. "Menuju Evolusi Ibadah Kristen Di Masa Pandemi Covid-19.” Jurnal Teologi Berita Hidup 3(2):150-59. doi: 10.24198/jkrk.v2i2.29126.7.

[6] Haryanto, SIndung. 2015. Sosiologi Agama. I. edited by Andien. Yogyakarta: AR-RUZZ MEDIA.

[7] Langfan, Onisimus. 2021. "Ibadah Online Di Masa Pandemi Covid-19: Implementasi Ibrani 12:28." Stella: Jurnal Teologi Dan Pendidikan Kristen $1(1): 16$.

[8] Makhmudah, Siti. 2015. "Dinamika Dan Tantangan Masyarakat Islam Di Era Modernisasi ( Pemikiran Dan Kontribusi Menuju Masyarakat Madani )." JURNAL LENTERA: Kajian Keagamaan, Keilmuan Dan Teknologi 1(September):242-59.

[9] Mulidiyah. Riza, Fauzi. Agus. 2021. "Multurual Community Rationality in Running Religious Activities in Pandemic Times". Jurnal Sosial dan Budaya. Volume 4. No. 2.

[10] Marzali, Amri. 2017. "Agama Dan Kebudayaan." Umbara 1(1):57-75. 10.24198/umbara.v1i1.9604.

[11] Mongan, Santi. 2020. "Pengaruh Ibadah Online Terhadap Transformasi Spiritual Dan Sosial Pada Warga Jemaat Gkii Jemaat Barang-Barang.” Jurnal Kuliah Metode Penelitian I - IAKN Toraja.

[12] Prijanto, Jossapat Hendra. 2021. "Gereja New Normal Dimasa Pandemik Sebagai Sarana Beribadah Dalam Kajian Pengajaran IPS.” Jurnal Kurios 1(1):14-24.

[13] Rosana, Ellya. 2015. "Modernisasi Dalam Perspektif Perubahan Sosial." Al-Adyan Jurnal Studi Lintas Agama 10(1):67-82.
[14] Shonhaji. 2012. "Agama Sebagai Perekat Social Pada Masyarakat Multikultural." Al-Adyan 7(2):119.

[15] SVD, Bernard Raho. 2019. Sosiologi Agama. 